into a separating glasse after the lungs have been well emptied of Aire. Severall persons of the Society trying it, some sucked up in one suction about three pintes of water, one six, another eight pintes and three quarters $\&$ c. Here was observed the variety of whistles or tones, which ye water made at the severall hights, in falling out of the glasse again.

"Mr. Evelyn's experiment was brought in of Animal engrafting, and in particular of making a Cock spur grow on a Cock's head.

"It was discoursed whether there bee any such thing as sexes in trees and other plants; some instances were brought of Palme trees, plum trees, hollies, Ash trees, Quinces, pionies, \&c., wherein a difference was said to be found, either in their bearing of fruit or in their hardnesse and softness, or in their medicall operations : some said that the difference which is in trees as to fertility or sterility may be made by ingrafting.

"Mention was made by Sr. Rob. Moray of a French Gentleman who having been some while since in England, and present at a meeting of the Society, discoursed that the nature of all trees was to run altogether to wood, which was changed by a certaine way of cutting them, whereby they were made against their nature to beare fruit, and that according as this cutting was done with more, or lesse, skill the more or less fruitfull the tree would bee.

"A proposition was offered by Sr. Robert Moray about the planting of Timber in England and the preserving of what is now growing.

"Mr. Boyle shew'd a Puppey in a certaine liquour, wherein it had been preserved during all the hott months of the Summer, though in a broken and unsealed glasse.

"Sir James Shaen proposed a Candidate by Sr. Rob. Moray."

The experiments were afterwards carried out by "Curators of Experiments," and some account is here added of this office, which was first held by Robert Hooke.

The whole of this condensed history extends to only eighteen pages. It is illustrated by two plates containing portraits, not indeed of the first six Presidents, for the portrait of Sir Cyril Wyche is wanting, but of the Presidents from Lord Brouncker to the Earl of Carbery, with this exception. If these can be continued in future issues, and especially if some likeness of Wyche, and of any others which may be at present missing can be discovered and reproduced, it will make a valuable series. Portraits of Henry Oldenburg, the first Secretary, and of Robert Boyle, one of the earliest Fellows, are also given.

This introductory history of the Society's birth and youth is followed by other matters of more or less historical interest; the text of the Charters, a history of the Statutes, a list of the Benefactors of the Society from "Carolus Secundus, Fundator," downwards; a history of the Trusts, and so forth. We are also furnished with accounts of other institutions which are controlled by, or more or less closely connected with, the Royal Society, from the Kew Observatory, which is governed by a Committee appointed by the Royal Society's Council, to "The Physick Garden" of Chelsea, in which the Society has, as we read, "only a reversionary interest."

With respect to the latter institution, its connection with the Royal Society at its first foundation was closer than at present, and was rather curious. The garden, now more generally known as "The Botanic Garden, Chelsea," was founded by Sir Hans Sloane in I722, by a deed which enacted "That the garden should at all times hereafter be continued as a Physick Garden" by the Society of Apothecaries, which Society should yearly present to the Royal Society "fifty specimens or samples of distinct plants, well dried and preserved, and which grew in the said garden the same year, together with their respective names or reputed names, and so as the specimens or samples of such plants be different, or specifically distinct, and no one offered twice, until the complete number of two thousand plants have been delivered." This tale of two thousand was completed, we learn, in the year 1762 .

The "Record" contains, furthermore, statements of the origin and progress of various branches of work which the Society is still carrying on-the Government Grant for Scientific Investigations, which finds its spring and source in a letter addressed in the year 1849 by Lord John Russell to the late Earl of Rosse ; the Society's publications, comprising, besides monographs, the Philosophical Transactions-a noble series of volumes extending over more than two centuries-the Proceedings, and the Catalogue of Scientific Papers. The lastnamed arduous undertaking is, indeed, one of the most important branches of work at present being carried on by the Society. Some account of it, reprinted in part in the volume under review, appearcd in our pages some time since (NATURE, vol. xlv. p. 338). Then there is the library, the pedigree of which, so far as concerns some of the classical and antiquarian literature, is traced through the Arundel Library (presented to the Society in its earliest days by Henry Howard, afterwards sixth Duke of Norfolk) to Bilibald Pirckheimer, the friend of Albrecht Dürer, and from him to Matthias Corvinus, King of Hungary.

Sundry lists are added-a list of instruments and relics, a list of portraits, a list of medals, of presidents, treasurers and secretaries of the Society, and of persons to whom the Society's medals have been awarded, all of which, though arranged, as we have said, in official form, and obviously intended for official purposes, contain matter which the future historian of science cannot fail to find of great importance. Here, for instance, we learn that the Society has in its possession many relics of Sir Isaac Newton, including his telescope, the mask from the cast of his face taken after death, and the MS. of the Principia from which the first edition was printed. Here we learn that the Society treasures Boyle's airpump, Petty's double-bottomed boat, Huyghens's aerial telescope, Priestley's electrical machine, and the original Davy's safety lamp; and here, under the names of the successive Presidents, we find biographical notes which should be of value. Weld's "History of the Society" carries us down only to the year 1830 , and it is but an imperfect compilation at the best. When the story is continued by some later hand-as continued it certainly ought to be-the prospective series, of which this "Record" forms the first volume, should considerably lighten the historian's task.

$\mathrm{X}$.

\section{SOARING FLIGHT}

SOME time ago we referred, in an article on "Soaring $S$ Machines" (NATURE, vol. liii. p. 30 I ; see also p. $365)$, to the experiments which Mr. Percy S. Pilcher had commenced to carry out in this country on the lines laid down by the late Herr Lilienthal in Germany. Since that time Mr. Pilcher has gained considerable experience both in the making and handling of these aëro-planes, and quite recently he was able to make a successful ascent and descent before numerous spectators, under conditions which were not very favourable. An idea of the general shape of the machine he used may be gathered from the six accompanying illustrations, which are enlargements of six out of the numerous pictures taken during flight by means of the cinematograph. The machine itself weighed fifty pounds, the framework being made of bamboo; the latter could be easily folded up but when spread out and carried the sail material covered

No. 1450 vor. 56] 
a surface area of 170 square feet. The tail, which can be seen at the back of the framework, consisted of two small surfaces placed horizontally and vertically; this had no means of movement in the lateral direction. but was capable of movement in the vertical direction above its horizontal position, about a fixed point in the framework. Such an arrangement as this was found to work best, as it eliminated to a great extent the liability of taking "headers." It plays, therefore, a rather important rôle in the machine.

When in a position for flight the arms of the operator, as far as the elbows, are placed in a stiff sleeve fitted to each side of the inner portion of the framework, and each hand grasps a small upright peg fixed also to the same support ; by this means a firm grip of the apparatus when off the ground may be obtained. It will thus be seen that when in flight the whole weight of the operator is on the two elbows; and it may be further stated that, to prevent the whole arm from becoming straight through any emergency requiring the movement of the body backwards, two fixed pads, supported on uprights attached to the framework, are positioned behind the shoulder-blades.

At the time of the flight (here illustrated) the wind was so light and variable in direction, that an ascent from even the elevated position taken up was almost inpossible. Means, however, were at hand by which one end of a thin fishing-line, 600 yards long, could be attached to the machine, while the other end passed through two blocks placed close together on the ground at a distance from the aero-plane of about 550 yards. These blocks were so arranged that a movement of the aerial machine in the horizontal direction corresponded to a fifth of the movement of the boys pulling the line.

The start was made at a given signal, the line being pulled by three boys, and Mr. Pilcher gradually left the ground, and soared gracefully into the air, attaining a maximum height of about 70 feet. After covering a distance of about I 80 yards the line suddenly parted, a knot having slipped. The only apparent difference this made was that the operator began now to slowly descend, his motion in the horizontal direction being somewhat reduced. A safe and graceful landing was made at a distance of 250 yards from the starting-point. The photographs illustrate that part of the flight previous to the attainment of the greatest height. It may be mentioned that the tension of the line amounted only to about $20 \mathrm{lb}$., so that only quite a weak pull was required to give the necessary lifting power: the trial indicated, however, that if the machine had been fitted with a small engine or motor, to give this amount of thrust by means of a screw or otherwise, perhaps an equal or further distance would have been covered.

Mr. Pilcher now proposes to employ, as soon as possible, a small and light engine indicating about four horse-power, this being considerably more than sufficient for flights of moderate length. It is, however, thought advisable to have rather too much than too little power to commence with, as a factor of safety. With this improvement it is hoped that further distances will be covered, and a nearer approximation to a flying machine will be attained.

In these attempts it must not be forgotten that there is always a certain amount of danger attached until we possess sufficient knowledge to guard against it. Experience, then, has to be dearly bought, and it requires no small amount of pluck and determination to trust one's self to these aerial crafts. Further, the serious experimenter must have both time and money at his disposal to successfully combat the many unforeseen difficulties that arise, and to carry out the alterations that must be made, to say nothing of the fact that each trial may result in the apparatus being completely or partially damaged. Those pursuing the inquiry must, therefore, have either considerable private means, or be supported

NO. I 450 , VOL. 56]

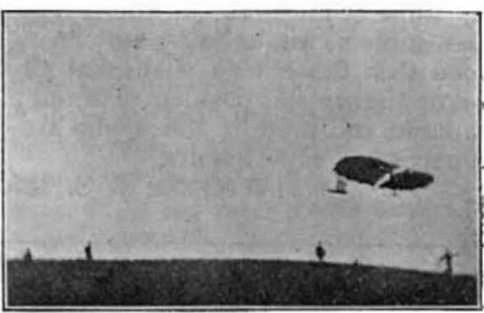

6

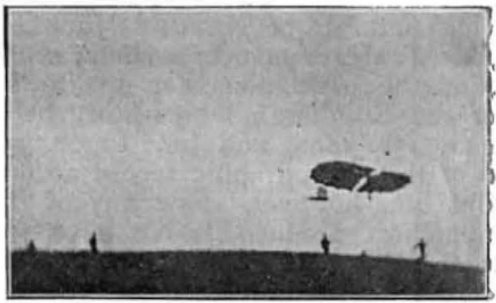

5

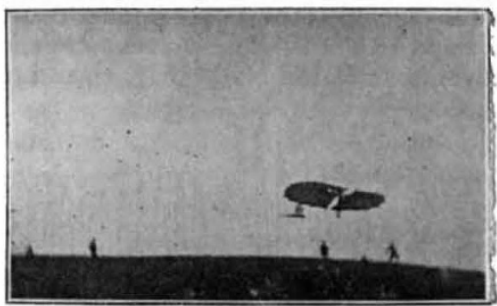

4

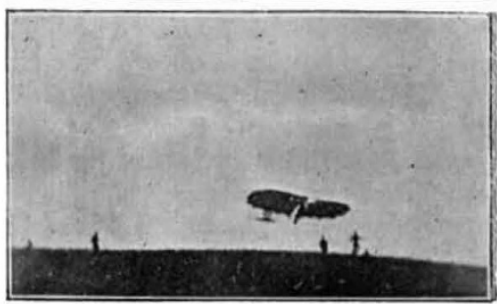

3

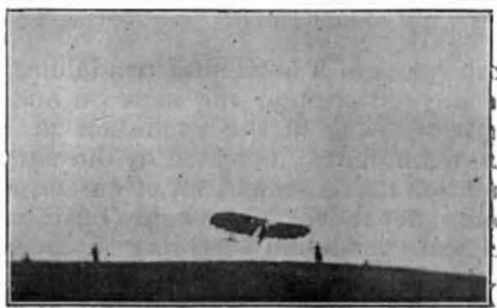

2

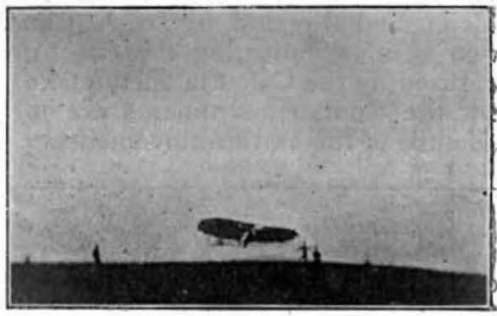

1

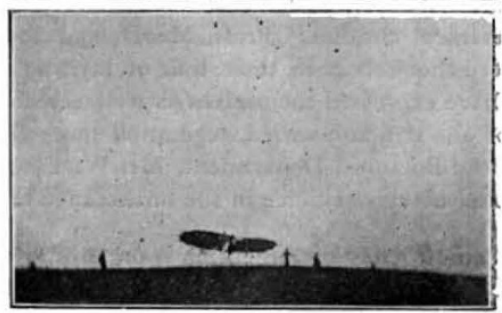


financially by those who take an interest in this big problem. The subject, we know, is still in its infancy; but it is hoped that those who wish that this country should take some part in this problem of aerial navigation should bear a hand and support those who are willing to carry out the necessary experiments.

WILLIAM J. S. LOCKYER.

\section{THE CALCUTTA EARTHQUAKE.}

$\mathrm{IN}$ a previous number of NATURE (June 24, vol. Ivi. p. 174), Mr. T. Heath gave an account, re the Indian earthquake, of the oscillations set up in the bifilar pendulum of the Edinburgh Observatory between the times June II, $23 \mathrm{~h}$. I $8 \mathrm{~m}$., and June I2, oh. $33 \mathrm{~m}$. The reproduction of the photographic record accompanying the letter did not, however, show any of the minor details of the effect produced. We have received a communication from Prof. P. Blaserna, in which these details are clearly depicted on the records obtained with the instruments erected at the Royal Geodetic Observatory of Rocca di Papa (Rome). The curves here shown illustrate the movements of the N.-S. (Fig. I), and the E.-W. of its foundation. The Congress will be under the patronage of the President of the Argentine Republic and the Ministers of Justice, Foreign Affairs, and Public Instruction. There will be seven sections, dealing respectively with exact sciences (pure and applied mathematics, astronomy, geodesy and topography), engineering, physics and chemistry, natural science, medical sciences (including hygiene and climatology), anthropology and sociology.

M. Hautefeuille, member of the Section of Mineralogy of the Paris Academy of Sciences, has been promoted to the rank of Officer of the Legion of Honour. M. J. Vinot has been made a Chevalier of the Legion of Honour.

Prof. Wm. Libbey, Jun., of Princeton, has succeeded in making the ascent of the Mesa Encantada, near Albuquerque, New Mexico, by the use of a cannon and life-line. The line was thrown over the mesa, and successively larger cords were attached, till after two days' labour a rope of sufficient strength to raise a man in a chair was in position. No archæological remains were discovered, except rocks piled up as if man had perhaps piled them. Tradition ran that the mesa had been inhabited until the means of access were swept away four centuries ago.
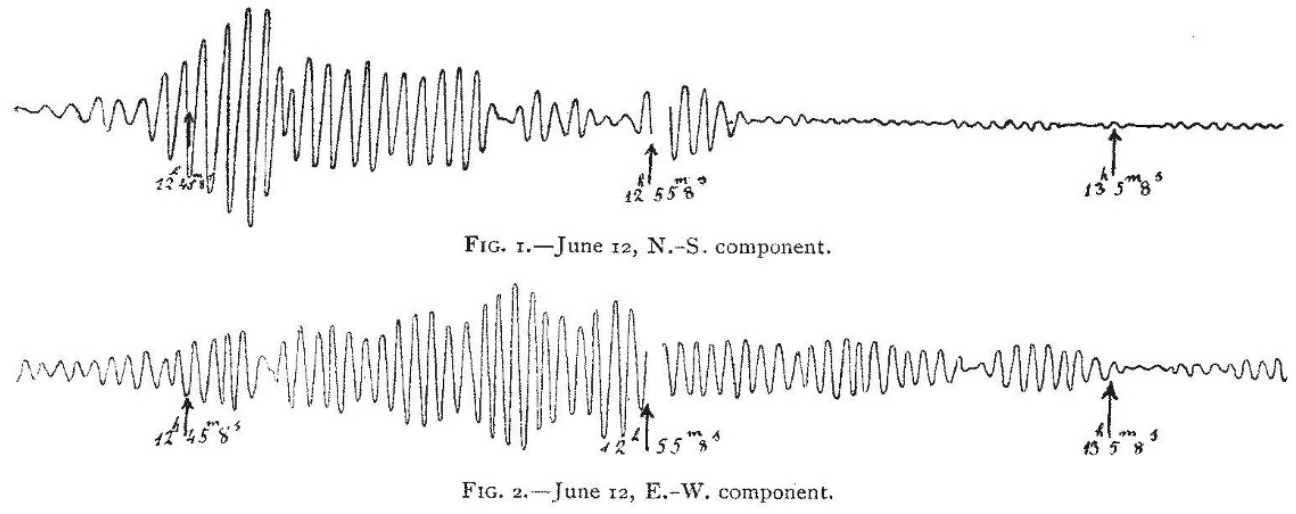

(Fig. 2) components of a horizontal pendulum, and show better than any description the increase and decrease in the length of swing of the pendulum at the times (intervals of ten minutes) indicated by the short arrows. We may mention that a second set of curves, made with another quite independent instrument (seismometograph with a vertical pendulum carrying a mass of 200 kilograms), recorded nearly similar disturbances at the same times. This latter instrument is also situated at Rocca di Papa, and directed by Dr. A. Cancani. The above curves, besides indicating the effect produced by the shocks caused by the Calcutta earthquake, show how very efficient the Roman instruments are for recording the minute details of the earth's movements.

\section{NOTES.}

THere seems some probability that Jamaica may be selected by the American Commission for the site of the proposed Tropical Botanical Station. Profs. MacDougal and Campbell have restricted themselves in their tour of investigation to that island, and have expressed themselves as well satisfied with the conditions of the rich and varied vegetation there found. The Director of the Botanical Department, Mr. W. Fawcett, is prepared to render every assistance in the furtherance of the object.

The Scientific Society of Argentina is organising a Congreso Cientifico Latino Americano, to be held at Buenos Ayres in April next, in commemoration of the twenty-fifth anniversary No. I 450 , VOL. 56]
THe Paris correspondent of the Times states that Dr. Robert Wurtz, professor at the Paris School of Medicine, has been chosen, as one of the leading French bacteriologists, for a mission in Abyssinia. He is to start for Jibutil and to go on direct to Adis Abeba, where, after having organised a department of vaccination, he will study the rinderpest and similar infectious maladies which chronically ravage Menelik's empire.

THE death is announced of Dr. W. Petzold, known by his contributions to geographical and astronomical literature.

We regret to announce the death of Prof. Victor Meyer, the distinguished professor of chemistry in the University of Heidelberg.

THE Government of Victoria is offering a bonus of roool. for the invention of an efficient and not too costly method of venti. lating mines.

THE Belgian Chamber of Representatives has voted an additional grant of sixty thousand francs in aid of M. de Gerlache's expedition to the South Pole.

THE statue of Charles Darwin, erected in his native town of Shrewsbury and in front of the school which for nine years he attended, was unveiled on Tuesday. The statue, which is of bronze, is the gift of the Shropshire Horticultural Society, and cost 1000 guineas.

THE thirty-fourth annual conference of the British Pharmaceutical Association was opened at Glasgow on Tuesday, under the presidency of Dr. Symes, of Liverpool. 